\title{
Herbal product labels: do they guide rational or irrational use?
}

Adriany Barreto de Souza ${ }^{1}$, Raimundo Fernandes Bento Filho ${ }^{1}$, Milena Rezende Brito ${ }^{1}$ (D),

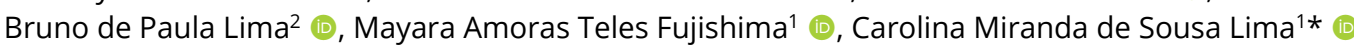

${ }^{1}$ Curso de Farmácia, Departamento de Ciências Biológicas e da Saúde, Universidade Federal do Amapá, Macapá, AP, Brasil ${ }^{2}$ Curso de Medicina, Departamento de Ciências Biológicas e da Saúde, Universidade Federal do Amapá, Macapá, AP, Brasil

*Corresponding author: carolina@unifap.br

\begin{abstract}
Objective: The purpose of this study was to analyze the primary and secondary labels of plantbased medicines. Method: This research has a cross-sectional and descriptive. The procedure consisted of analyzing 100 labels of medicinal plant-based products used by elderly people from (in) Macapá-AP, in 2017. A script was prepared to verify their adequacy to health standards based on the Brazilian legislation (commercial name, botanical nomenclature, active ingredients, concentration, route of administration, age-restricted use, quantity and pharmaceutical form, preservation care, company name, CNPJ - Brazils's companies registration number, composition, SAC, expiration date, manufacture and batch), descriptive analysis of the data was performed (protocol number 38400314.9.0000.0003). Results: Only 4\% of the products completely met the analyzed criteria. One of the main problems observed was the absence of a uniform standard of presentation of information on the packaging. About $7 \%$ of these products did not present any information besides the popular name of the medicinal plant used, 37\% of the packages (or labels) contain statements and images that induce self-medication, errors in use, or references to "natural medicine", besides, transmitting the idea that the product has superior properties to drugs on the market. Conclusions: The results obtained suggest that the packaging of medicinal plant-based products induces the irrational use of medicines due to the lack of adequate information, as well as the presence of inadequate makenting strategies, in accordance with current national legislation.
\end{abstract}

Keywords: Drug. Packaging. Legislation. Herbal Medicine.

\section{How to cite}

Souza AB, Bento Filho RF, Brito MR, Lima BP, Fujishima MAT, Lima CMS. Herbal product labels: do they guide rational or irrational use?. Rev Ciênc Farm Básica Apl. 2022;43:e760.

https://doi.org/10.4322/2179-443X.0760

\section{INTRODUCTION}

In Brazil, it is estimated that about $82 \%$ of the population uses medicinal plant products in health care, either through traditional knowledge, popular medicine or the official health system, as a scientific practice, guided by the guidelines and principles of SUS - Unified Health System ${ }^{1}$.

Financial support: None.

Conflicts of interest: The authors have no conflict of interest to declare.

The study was carried out at Frei Daniel community center in Samarate and at the Universidade Federal do Amapá, Macapá,

AP, Brasil.

Received on October 01, 2021. Accepted on November 25, 2021. 
Due to the great demand for products based on medicinal plants, it is necessary to investigate how these products are being offered to the consumer, according to specific legislation and scientifically established criteria $^{2}$, so that they do not bring risks to the collective health.

Among the many aspects that need to be evaluated, the packaging in which the medicines or products used in health are included, because the packaging is the first contact of the patient with the "treatment", serving as a barrier to its irrational use or stimulus for the rational use of medicines or herbal medicines.

When drug packaging presents problems related to the interface, such as low legibility, product identification, and also related to safety due to lack of data that are lost with handling and difficulty in opening the packaging ${ }^{3}$, the general population is at risk. Health risks can be varied internationally as reported in a study by Ekar and $\mathrm{Kreft}^{4}$, where they conclude that the intentional addition of synthetic substances, unintentional other plant species or mislabeling can cause various adverse reactions or even death.

Despite this, few researches on the subject were found. In 2015, 87 labels of Chilean boldus (Pneumus Boldus) tea and chamomile tea in Fortaleza-Ce were analyzed, and no labels were found that met $100 \%$ of the current legislation at the time ${ }^{5}$. In 2019, 17 labels were analyzed in São Luís and the most common information found was the popular name of the plant used, and labels that met $100 \%$ of the current legislation at the time were not found ${ }^{6}$.

Another work that highlighted the importance of the information on the label was carried out by Marques et al. ${ }^{7}$, who concluded that the botanical name helps in the assessment of acute and chronic toxicity when necessary, with this information being essential in the label ${ }^{7}$. It was also evident that in the northern region of Brazil, despite the frequent use of these products, studies are still very rare.

The greatest reflections of labeling problems should be associated with the irrational use of medicines, including medication errors. This should represent pharmacoeconomic impacts on health care, in addition to raising the risks of hospitalization and death of the population, especially in regions with low health support, such as the Brazilian Amazon, where the use of medicinal plants and herbal medicines is routinely performed.

Global initiatives to standardize and harmonize drug labels and packaging are essential to reduce medication errors ${ }^{8}$. Given this, the purpose of this study was to analyze the primary and secondary labels of plant-based medicines used by the elderly in the city of Macapá Amapá in 2017, in accordance with Brazilian legislation.

\section{METHODS}

This research has a cross-sectional and descriptive character and data collection (labels) occurred between July and December 2017. The study was conducted in Macapá - Amapá in

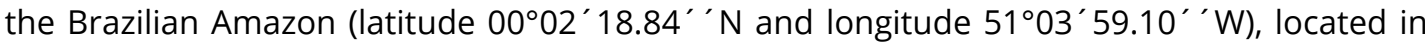
the Northern Region of Brazil, in the Guianas Plateau, bordered to the west and south by the state of Pará, by French Guiana to the north, by the Atlantic Ocean to the northeast, by the mouth of the Amazon River to the east, and to the northwest by Suriname.

Samples. 132 samples of medicinal plant-based medicines used by the elderly were donated for label analysis, of which only 100 were eligible for this study. These elderly people participated in the project "Evaluation of the quality of herbal preparations and the impact of their use in the pharmacotherapy of elderly patients", where the medicinal plant-based medicines packages were given for microbiological quality control and the labels were removed for the development of this study.

Elderly people at the time of donation of medicinal plant-based medicines samples reported that the acquisition was carried out in fairs, markets and drug stores or compounding pharmacies.

Inclusion and exclusion criteria. Complete and legible labels of products purchased through donation from consumers of these products were included. Products that were not legible and labels that were torn or ripped were excluded. 
Data collection tools. A script was prepared based on the legislation RDC 71 of December $22,2009^{9}$, to analyze the labels of herbal products with the following variables: commercial name, botanical nomenclature, active ingredients, concentration, route of administration, age-restricted use, quantity and pharmaceutical form, preservation care, company name, CNPJ (Brazil's companies registration number) composition, SAC, expiration date, manufacture and batch.

The presence of information contained on secondary packaging was also analyzed, such as: "Technical information to the patient: See package insert", "Keep the product at room temperature and protected from light and moisture", "All medication should be kept out of the reach of children", "Follow the instructions for use correctly", "If symptoms do not disappear, seek medical advice" according to RDC 71/20099.

Data analysis. Data analysis was performed using BioEstat version 5.3 software.

\section{RESULTS}

One hundred labels of medicinal plant-based products sold in Amapá were analyzed. According to the packaging, traditional herbal products presented the highest frequency among the products analyzed, corresponding to $42 \%$ (Graph 1 ).

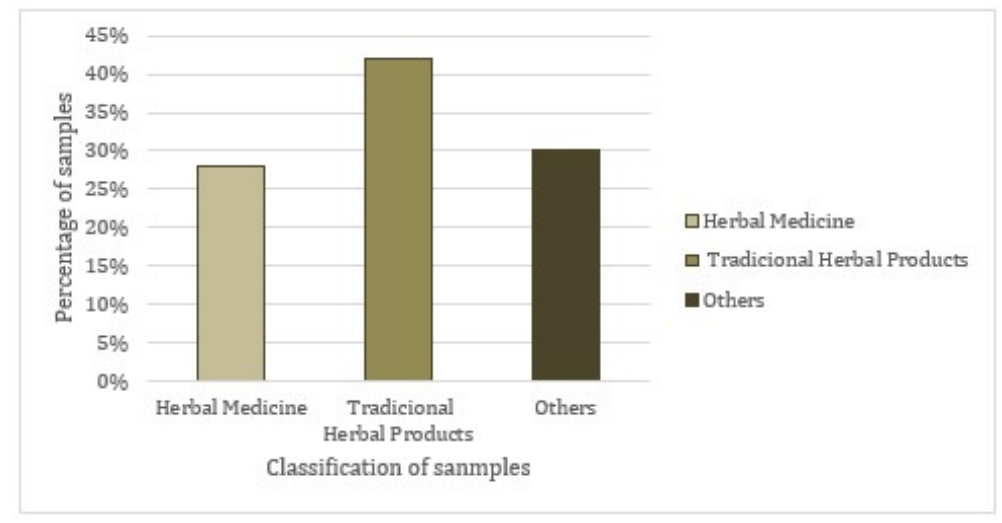

Graph 1 - Product samples according to the labels

It was observed that only $4 \%(4 / 100)$ of the analyzed samples met all the criteria of the current Brazilian legislation (Table 1).

Table 1 - Products that met or did not meet the criteria of Anvisa's legislation No. 71 of December 22, $2009^{9}(\mathrm{~N}=100)$.

\begin{tabular}{cccc}
\hline Products Analyzed & Attended \% (N) & Partially \% (N) & Did not answer \% (N) \\
\hline Traditional Herbal Products & $0 \%$ & $12 \%(12)$ & $30 \%(30)$ \\
Herbal Medicine & $4 \%(4)$ & $24 \%(24)$ & $0 \%(0)$ \\
Others & $0 \%(0)$ & $10 \%(10)$ & $20 \%(20)$ \\
Total & $4 \%(4)$ & $46 \%(46)$ & $50 \%(50)$ \\
\hline
\end{tabular}

In Table 2 the most common pharmaceutical forms were identified on the labels of the samples, where $18 \%$ of samples were designated as "Not described" because they did not have any information about the pharmaceutical forms, and the most frequent pharmaceutical form was capsules with $14 \%$. Among the categories that did not have the pharmaceutical forms on the product label, 50\% (9/18) were traditional herbal products, 16.7\% (3/18) were herbal medicine and $33.3 \%(6 / 18)$ were others products that contained plants and animal derivatives in their formulation. 
Table 2 - Frequency of pharmaceutical forms identified on the labels.

\begin{tabular}{ccc}
\hline Pharmaceutical Form & $\mathbf{N}$ & $\%$ \\
\hline Not described & 18 & 18 \\
Capsule & 14 & 14 \\
Syrup & 13 & 13 \\
Tincture & 12 & 11 \\
Ointment & 11 & 9 \\
Oil & 9 & 8 \\
Gel & 8 & 6 \\
Tea & 6 & 3 \\
Oral Solution & 3 & 2 \\
Elixir & 2 & 2 \\
Cream & 2 & 1 \\
Tablet & 1 & 1 \\
Oral antiseptic & 1 & 100 \\
Total & 100 & 1 \\
\hline
\end{tabular}

In the samples of medicinal plant-based product labels analyzed, $90 \%$ contained commercial name and $88 \%$ validity period as shown in Table 3.

Table 3 - Frequency of information contained in primary labels of medicinal plant-based product.

\begin{tabular}{ccc}
\hline ITEMS ANALYZED & N & \% \\
\hline Commercial name & 90 & 90 \\
Expiration date & 88 & 88 \\
Active ingredients & 86 & 86 \\
Pharmaceutical form & 85 & 85 \\
Medicine quantity & 82 & 82 \\
Manufacture & 79 & 79 \\
Name of the company that holds the registration & 75 & 75 \\
CNPJ & 67 & 67 \\
SAC & 55 & 55 \\
Composition & 48 & 48 \\
Batch & 46 & 46 \\
Restriction by age group & 42 & 42 \\
Botanical nomenclature & 40 & 40 \\
Conservation care & 38 & 38 \\
Administration route & 37 & 37 \\
Concentration & 10 & 10 \\
\hline
\end{tabular}

Of the samples analyzed, only 4\% had secondary packaging, of which $75 \%$ (3/4) were herbal medicine, as described in Table 4.

Table 4 - Frequency of information contained in secondary labels $(n=4)$.

\begin{tabular}{|c|c|c|}
\hline ITEMS ANALYZED & $\mathbf{N}$ & $\%$ \\
\hline Commercial name & 4 & 100 \\
\hline Conservation care & 4 & 100 \\
\hline Name of the company that holds the registration & 4 & 100 \\
\hline CNPJ & 4 & 100 \\
\hline SAC & 4 & 100 \\
\hline Expiration date & 4 & 100 \\
\hline Batch & 4 & 100 \\
\hline Botanical Nomenclature & 3 & 75 \\
\hline Active ingredients & 3 & 75 \\
\hline Concentration & 3 & 75 \\
\hline Route of administration & 3 & 75 \\
\hline Pharmaceutical form & 3 & 75 \\
\hline Medicine quantity & 3 & 75 \\
\hline Composition & 3 & 75 \\
\hline Manufacture & 3 & 75 \\
\hline Age restriction & 2 & 50 \\
\hline
\end{tabular}


It was also observed that $43.7 \%$ ( $35 / 82$ that contained labels) of the labels of the products analyzed in this study contained images and/or statements that induce self-medication. Of these, 19.5\% (16/82) were traditional herbal products and 23.2\% (19/82) were other herbal and animal-derived products. Some labels also contained sentences that induced to buy these products. The phrases were classified as: indication of natural product, religion and indication of specific treatment, as described in the table below (Table 5).

Table 5 - Description of inappropriate phrases present on labels.

\begin{tabular}{|c|c|}
\hline Types & Phrases Used \\
\hline & "100\% Natural." \\
\hline \multirow[t]{4}{*}{ Natural Product Indication } & "Product only based on Medicinal Plants." \\
\hline & "Handmade product." \\
\hline & "Only Jesus Saves." \\
\hline & "Miracle product." \\
\hline Religion & "Give your way to the Lord, trust him and he will do his best." \\
\hline & "I can do everything through Him who strengthens me." \\
\hline & "Cancer bottle." \\
\hline \multirow[t]{2}{*}{ Appealing Indication } & “Asthma Syrup." \\
\hline & "Cure everything." \\
\hline
\end{tabular}

Of the total samples, $7 \%$ of these products did not present any information besides the popular name of the medicinal plant and or active principle used (Table 6) and copaíba (Copaiba langsdorffii) was the most cited product on the packaging (5.02\%).

Table 6 - Frequency of medicinal plants described on the labels of the samples studied.

\begin{tabular}{|c|c|c|c|}
\hline Popular Name & Botanical Nomenclature & $\mathbf{N}^{\circ}$ & $\%$ \\
\hline Copaíba & Copaiba langsdorffii & 13 & 5.02 \\
\hline Arnica & Arnica montana $L$. & 11 & 4.25 \\
\hline Jatobá & Hymenaea courbaril L & 10 & 3.86 \\
\hline Verônica & Veronica officinalis & 9 & 3.47 \\
\hline Alho & Allium sativum & 8 & 3.09 \\
\hline Andiroba & Carapa guianensis & 8 & 3.09 \\
\hline Eucalipto & Eucalyptus globulus & 8 & 3.09 \\
\hline Gengibre & Zingiber officinale & 8 & 3.09 \\
\hline Barbatimão & Stryphnodendrom adstrigens & 7 & 2.70 \\
\hline Jucá & Caesalpinia ferrea mart & 7 & 2.70 \\
\hline Unha de gato & Uncaria tomentosa & 7 & 2.70 \\
\hline Aroeira & Schinus terebinthifolius & 6 & 2.32 \\
\hline Arruda & Ruta graveolens & 6 & 2.32 \\
\hline Boldo & Peumus boldus & 6 & 2.32 \\
\hline Limão & Citrus cf. limon & 6 & 2.32 \\
\hline Quebra-Pedra & Phyllanthus niruri & 6 & 2.32 \\
\hline Sucupira & Pterodon emarginatus & 6 & 2.32 \\
\hline Sucuúba & Himatanthus sp. & 6 & 2.32 \\
\hline Carqueja & Baccharis trimera & 5 & 1.93 \\
\hline Hortelã & Mentha x piperita $L$. & 5 & 1.93 \\
\hline Maracujá & Passiflora incarnata & 5 & 1.93 \\
\hline Castanha da índia & Aesculus hippocastanum $L$ & 4 & 1.54 \\
\hline Catuaba & Trichilia catiguá & 4 & 1.54 \\
\hline Cumarú & Dipteryx odorata & 4 & 1.54 \\
\hline Ipê roxo & Handroanthus impetiginosus & 4 & 1.54 \\
\hline Alcachofra & Cynara scolymus L. & 3 & 1.16 \\
\hline Alecrim & Rosmarinus officinalis & 3 & 1.16 \\
\hline Babosa & Aloe vera & 3 & 1.16 \\
\hline Camomila & Matricaria recutita & 3 & 1.16 \\
\hline Cana do brejo & Costus spicatus & 3 & 1.16 \\
\hline Chapéu de couro & Echinodorus macrophyllus & 3 & 1.16 \\
\hline Gergelim preto & Sesamum indicum L & 3 & 1.16 \\
\hline Marapuama & Ptychopetalum olacoides & 3 & 1.16 \\
\hline
\end{tabular}


Herbal product labels: do they guide rational or irrational use?

Table 6. Continued...

\begin{tabular}{cccc}
\hline Popular Name & Botanical Nomenclature & $\mathbf{N}^{\circ}$ & $\%$ \\
\hline Pariri & Arrabidaea chica & 3 & 1.16 \\
Pequi & Caryocar brasiliense & 3 & 1.16 \\
Romã & Punica granatum & 3 & 1.16 \\
Uxi Amarelo & Endopleura uchi & 3 & 1.16 \\
Anis estrelado & Illicium verum & 2 & 0.77 \\
Assacu & Hura crepitans L. & 2 & 0.77 \\
Others & & 48 & 18.53 \\
Total & & 259 & 100 \\
\hline
\end{tabular}

Only $4 \%$ of the products completely met the criteria analyzed. One of the main problems observed was the absence of a uniform standard for the presentation of information on product packaging, not only among different manufacturers, but also among products from the same manufacturer.

\section{DISCUSSION}

The first essential information that must be available to the consumer/patient of a drug or herbal medicine is which category it actually belongs to, as there is a subdivision suggested by the National Health Surveillance Agency - Anvisa, which also directs the quality standard and the level of evidence that these products associated with plants reaches for the proposed indication, which helps in their rational use.

The herbal medicine and traditional herbal product are differentiated by clinical tests of safety and effectiveness or by the approval for the time of safe and effective traditional use, in the case of traditional herbal products, according to the RDC No. 26 of May 13, 2014 ${ }^{10}$, which already assists a safe and conscious choice of the product, considering that they are marketed without the requirement of a prescription or other health care professional, considered without a prescription.

The traditional herbal products in this and other studies $1,5,11,12$ were the most frequently used by the population, probably due to the ease of access, the lower cost of these products, the traditional use/indications and the strong cultural history of the Amazon region.

In this study, products containing vegetable and animal derivatives in their composition were categorized as "others", as there was no description for this type of product in the consulted Anvisa regulation documents. However, these products could not be excluded from the analysis of this study, given their importance for the Amazonian culture, being commonly used by the general population. Brazil holds a huge biodiversity and the popular and traditional practices accompany this diversity, pointing to the peculiarity of each region and the need for this aspect to be observed by health authorities.

In addition, an herbal medicine or a traditional herbal product is not considered to be one that includes isolated or highly purified active substances in its composition, whether synthetic, semi-synthetic or natural ${ }^{10}$. Therefore, it is important to emphasize that in this study there was a small amount of isolated natural substances samples with their associations with other extracts, according to the label descriptions, and these were allocated in the category of traditional herbal products. Perhaps this happens because these products are not widely sold in the region, or are costly, or are not culturally "attractive" for the population studied.

In a study conducted by Lima et al. ${ }^{13}$, it is observed that the probability of adverse drug reaction (ADR) in the elderly people who use herbal medicines is $93.4 \%$, and the probability of ADR in the elderly people who do not use herbal medicines is $90.51 \%$. This information suggests that health authorities should be vigilant regarding the consumption of medicinal plant-based products, especially by the elderly population, considering that in Brazil they are sold without a prescription. In addition, this sale often takes place in places without the supervision of health professionals, without guidance and without a proper labeling, such as open markets, which makes the general population even more vulnerable.

In Macapá, the practice of herbal medicines is inserted in the unified health system (SUS) at the Regional Center for Natural Treatments (CRTN), in primary care, both with the 
prescription and dispensing of medicinal plant-based products (IEPA), where there is a pharmacy of herbal medicines. It is important to emphasize that the use of medicinal plants for health care in the Amazon is cultural, which is why it occurs with or without guidance from health teams, the sale of products is carried out without prescription and is often not restricted to health establishments.

According to Moura et al. ${ }^{14}$, most herbal medicines are without prescription or are dispensed without the need for a prescription, which facilitates the population's access and, therefore, self-medication. Adding to the persistence of the belief in the safety of herbal products, possible adverse reactions or toxic effects are not harmful. This should also contribute to the lack of care for their labels by producers or manufacturers.

The quality of information contained on the labels of herbal medicines should be in accordance with the legislation and provide safe use without presenting health risks. According to Petrovick et al. ${ }^{15}$ the labeling of drug packaging is of utmost importance, not only for its formal character, but also for its power of information and influence on the user.

The products that presented statements that induce self-medication such as " $100 \%$ natural product", "Cancer bottle" or "Kidney compounds", contained inappropriate images such as women wearing only lingerie and were classified as traditional herbal product and "others". Thus, some marketing strategies are often used in order to increase profits at the expense of the quality of the information provided, exerting a power of influence on the purchase of these products, which can lead to indiscriminate purchase and use ${ }^{16}$.

Among the information contained on the labels, the pharmaceutical form was present in most samples, with capsules presenting the highest frequency, demonstrating the preference for the production of this solid pharmaceutical form due to its good acceptance by users. About the other pharmaceutical forms mostly frequent in the samples, syrups and tinctures are older forms and are widely used in traditional medicine.

Most samples had indication on the label of the use of more than one plant, being considered a compound product. However, compound products are difficult to estimate which active ingredients are present and in what concentration, hence the low number of labels analyzed containing information on the concentration used. In addition, it was possible to identify which plant species are most frequent in these products. Among the species we have Copaíba (Copaifera sp), followed by Arnica (Arnica montana L.) and Jatobá (Hymenaea courbaril L.).

According to Santana et al. ${ }^{11}$, plants belonging to the Copaifera genus are the most studied medicinal plants in the world and typical of the southeastern, central-western, and Amazon regions of Brazil. A product called "Copaiba oil" is extracted through an incision in the trunk of the copaíba tree. Its use is very common due to its anti-inflammatory and healing therapeutic indication.

As specified by Bussières ${ }^{17}$, the lack of standardization in the labels of medicinal plants products allows some manufacturers to sell these products without providing data that could contribute to the consumer.

Thus, the standardization of these labels in accordance with the regulation is essential to promote the rational use of these products, as without a regulation that encompasses all herbal products and also those with animal derivatives, producing companies would normally indicate in large quantities on the labels positive aspects of the product, omitting information such as, for example, use restrictions and contraindications.

Several items, taking into account the RDC No. 71 of December 22, 2009', were absent on some primary packaging labels, which directly implies the safety and health of the patient. The item that was most absent was "concentration". The information on the labels of medicines without prescription, such as concentration, should be sufficiently clear and complete so that users can understand them and use the product effectively, rationally and safely.

The second item with the highest absence was "route of administration" and should be considered a very important item on the packaging, as there are several factors such as therapeutic response, intoxication, bioavailability that can lead to possible errors and consequently cause harm to the consumer, varying from drug misuse to injuries and deaths.

The third item that presented the greatest inadequacy was "conservation care". The description of conservation care is essential for the correct storage of the product by the 
establishment and by the user, which contributes to the maintenance of the physicochemical stability and quality of the product during its shelf life. For products based on medicinal plants, this becomes even more difficult, because they present more complex characteristics, being more likely to deteriorate, especially during storage, if the product is inadequately exposed to moisture, heat, among others. Degradation can cause loss of the active component, production of inactive metabolites, and even production of toxic substances.

The correct use of these products also requires the presence of basic information on the labels, such as expiration date, pharmaceutical form and composition. However, such items were reported in most samples.

In the secondary packaging samples, most items were present, but it should be taken into account that the quantity of products that had secondary packaging is smaller than the quantity that had primary packaging. The item that presented the lowest quantity in the secondary packaging was "restriction by age group", the restriction of use is defined as the limitation of use a drug in terms of the target population, which can be for pediatric and/or adult use. This item is, therefore, essential for user safety, especially in the pediatric and/or geriatric population.

The problems that can occur to the population with quality deviations in the labeling of medicines are of interest to everyone, especially those involved in health actions, as they can bring risk to the population that consumes these types of products. Measures can be taken as evidenced by the updated publication of legislation in this regard by Anvisa and through increased inspection in the establishments where the illegal sales of these products take places.

Thus, the National Policy of Medicinal Plants and Herbal Medicines ${ }^{18}$ presents the need for convergence and harmony between sectorial policies, as these are factors that must be considered in the development of public policies in the area of medicinal and herbal plants, recognizing practices and knowledge, in different ways of use, from those of local communities to those of national industries, passing through a multitude of other arrangements of production chains in medicinal and herbal plants sector.

The sanitary registration of medicines is the tool by which the sanitary surveillance must to control the entry and circulation of medicines sold in the country, being an important information base for the application of actions, control and inspections. From the proper control, registration, and inspection of herbal medicine and traditional herbal products, the analyzed samples that fully met the criteria, all were herbal medicines. However, there are still many products that are sold mainly in fairs or traditional houses without any sanitary certification, or care in their production, packaging, and storage, exposing the population to possible risks of intoxication, contamination, medication errors, and drug interactions.

Therefore, constant monitoring is necessary to ensure the safe production of these products, one of the factors that can occur in the development of products obtained from medicinal plants is the use of counterfeit plant material, commented by Souza-Moreira et al. ${ }^{19}$ on the importance of knowing the correct species by its scientific name by collectors and distributors of material to help avoid errors in the manufacture of these products, as there is a wide variety of popular nomenclatures for different species.

These packages, primary and secondary, can undoubtedly influence the consumption of these medicinal plant-based products, medicines, traditional products or herbal products, and currently, with the lack of information or the amount of inadequate information, it is probably stimulating their irrational consumption, without proper guidance, warnings about age group, concentration, mode of use and images that induce consumption or the idea of safety, no information referring to risk or recommending the search for the health services in case of persistence of symptoms.

The most neglected products, whose label information did not contain the pharmaceutical form, for example, were traditional herbal products. These are the products most easily found in fairs and popular markets and whose consumption is more related to cultural aspects, probably for this reason they lack basic information on the label. In addition, the lack of inspection, guidance of traders, producers, consumers of this type of product should aggravate the maintenance of the disinformation cycle. 
Furthermore, pharmacovigilance of medicinal plants is also very important and requires more information on preparation and administration methods, adverse events, contraindications and preventive measures to improve the risk effectiveness. Since the risks exist and are significant, the need for more effective control of the sale and consumption of herbal medicines is emphasized. Health education strategies, exercises and workshops for the safe use of these therapies for the elderly people and the general population are essential for public health and patient safety ${ }^{12}$.

So, despite being natural, coming from nature, Anvisa states that we need to find the balance point between our traditions and the dissemination of popular knowledge in a safe and rational way, so that the result is actually improved health, with low risk and optimal benefit achieved.

\section{CONCLUSION}

Of the samples analyzed, $96 \%$ of the products showed quality deviations from current legislation and only $4 \%$ fully met the analyzed criteria, suggesting that the packaging induces the irrational use of herbal medicines due to lack of adequate information, as well as the presence of inadequate marketing strategies.

The highest frequency of errors was found in samples of traditional herbal products and in associations of plants with products of animal origin (others). This lack of standard in labeling can influence it to different degrees, indicating that there is no uniformity in the information contained in the labels and leading to various adverse events, mainly medication errors.

Furthermore, the difference between the application of labeling rules between synthetic drug and herbal medicines is remarkable, where apparently failures in the labeling seems acceptable due to the perception of safety of the consumed products, which must be reassessed by the health authorities and the population in general.

\section{ACKNOWLEDGEMENTS:}

The direction, employees and volunteers of the Center for Human and Social Promotion Frei Daniel de Samarate.

\section{REFERENCES}

1. Silva NCS, Vitor AM, Bessa DHS, Barros RMS. A utilização de plantas medicinais e fitoterápicos em prol da saúde. ÚNICA Cad Acad. 2017;3(1):1-5.

2. Melo JG, Martins JDGR, Amorim ELC, Albuquerque UP. Qualidade de produtos à base de plantas medicinais comercializados no Brasil: castanha-da-índia (Aesculus hippocastanum L.), capim-limão (Cymbopogon citratus (DC.) Stapf) e centela (Centella asiatica (L.) Urban). Acta Bot Bras. 2007;21(1):27-36. http://dx.doi.org/10.1590/S0102-33062007000100004.

3. Lucio CC. Embalagens de medicamentos: diretrizes para o desenvolvimento [tese]. Bauru: Faculdade de Arquitetura, Artes e Comunicação, Universidade Estadual Paulista "Julio de Mesquita Filho"; 2013.

4. Ekar T, Kreft S. Common risks of adulterated and mislabeled herbal preparations. 2018. Food Chem Toxicol. 2019;123:288-97. http://dx.doi.org/10.1016/j.fct.2018.10.043. PMid:30339960.

5. Silva BR No. Análise de rótulos de garrafadas comercializadas no mercado central de São Luís - MA Ponta Grossa: Atena; 2019. (Prevenção e Promoção de Saúde; vol. 4). http://dx.doi.org/10.22533/at.ed.3041909123.

6. Soares FP, Freire NM, Souza TR. Avaliação farmacognostica e da rotulagem das drogas vegetais boldo-do-chile (Peumus boldus Molina) e camomila (Matricaria recutita L.) comercializadas em Fortaleza, CE. Rev Bras Plantas Med. 2015;17(3):468-72. http://dx.doi.org/10.1590/1983084X/10_115.

7. Marques JO, Oliveira MFF, Lacerda GA. Efeito alelopático e análise dos rótulos de garrafadas comercializadas no Mercado Municipal de Montes Claros - MG. Rev Bras Plantas Med. 2015;17(4, supl. 3):1134-41. http://dx.doi.org/10.1590/1983-084x/14_160. 
8. Cândido RCF. Rotulagem e embalagem de medicamentos com foco na segurança do paciente é tema de encontro internacional [Internet]. Belo Horizonte: Institute for Safe Medication Practices; 2018 [cited 2019 Jan 21]. Available from: https://www.ismp-brasil.org/site/noticia/rotulagem-e-embalagemde-medicamentos-com-foco-na-seguranca-do-paciente-e-tema-de-encontro-internacional/

9. Brasil. Ministério da Saúde. Resolução de Diretoria Colegiada n 71, de 22 de dezembro de 2009. Estabelece regras para a rotulagem de medicamentos. Diário Oficial da União; Brasília; 2009:3.

10. Brasil. Ministério da Saúde. Resolução de Diretoria Colegiada n²6, de 13 de maio de 2014. Dispõe sobre o registro de medicamentos fitoterápicos e o registro e a notificação de produtos tradicionais fitoterápicos. Diário Oficial da União; Brasília; 2014:52.

11. Santana SR, Bianchini-Pontuschka R, Hurtado FB, Oliveira CA, Melo LPR, Santos GJ. Uso medicinal do óleo de copaíba (Copaifera sp.) por pessoas da melhor idade no município de Presidente Médici, Rondônia, Brasil. Acta Agron. 2014;63(4):361-6. http://dx.doi.org/10.15446/acag.v63n4.39111.

12. Lima CMS, Fujishima MAT, Lima BP, Mastroianni PC, Sousa FFO, Silva JO. Microbial contamination in herbal medicines: a serious health hazard to elderly consumers. BMC Complement Med Ther. 2020;20(1):17. http://dx.doi.org/10.1186/s12906-019-2723-1. PMid:32020854.

13. Lima CMS, Fujishima MAT, Santos BÉF, Lima BP, Mastroianni PC, Sousa FFO, Silva JO. Phytopharmacovigilance in the elderly: highlights from the Brazilian Amazon. Evid Based Complement Alternat Med. 2019;2019:9391802. http://dx.doi.org/10.1155/2019/9391802. PMid:30854018.

14. Moura CM, Carvalho ACB, Falcão DP. Rotulagem de medicamentos fitoterápicos industrializados: está adequada às diretrizes legais? Vig Sanit Debate. 2014;2(2):60-6. http://dx.doi.org/10.3395/vd.v2i2.140.

15. Petrovick GF, Petrovick PR, Teixeira HF. Análise da adequação da rotulagem de medicamentos industrializados. Infarma. 2004;16(7-8):54-8.

16. Brasil. Ministério da Saúde. Agência Nacional de Vigilância Sanitária. Estudo comparado: regulamentação da propaganda de medicamentos. Diário Oficial da União; Brasília; 2005.

17. Bussières JF, Lebel D, Voytenko S, Vaquer G. Développement d'un concept et d'un processus de gestion de l'identité numérique d'un produit en établissement de santé. Can J Hosp Pharm. 2009;62(5):406-14. http://dx.doi.org/10.4212/cjhp.v62i5.829. PMid:22478924.

18. Brasil. Ministério da Saúde. Secretaria de Ciência, Tecnologia e Insumos Estratégicos. Departamento de Assistência Farmacêutica. Política e Programa Nacional de Plantas Medicinais e Fitoterápicos. Brasília: Ministério da Saúde; 2016.

19. Souza-Moreira TMO, Salgado HRN, Pietro RCLR. O Brasil no contexto de controle de qualidade de plantas medicinais. Rev Bras Farmacogn. 2010;20(3):435-40. http://dx.doi.org/10.1590/S0102$695 \times 2010000300023$.

\section{Author contributions:}

Souza, AB; Bento Filho, RF; Brito, MR; Lima, BP; Fujishima, MAT; Lima, CMS. 